\title{
Article \\ Ekklesia and Ecumenism in the Body of Christ: Unity from the Ground-Up
}

\author{
Anastasia Wendlinder \\ Gonzaga University, 502 East Boone Avenue, Spokane, WA 99258-0102, USA; wendlinder@gonzaga.edu
}

Received: 9 October 2018; Accepted: 22 November 2018; Published: 28 November 2018

\begin{abstract}
This article explores the implications for Christian unity from the perspective of the lived faith community, the ekklesia. While bilateral and multilateral dialogues have borne great fruit in bringing Christian denominations closer together, as indeed it will continue to do so, considering how the ecclesiological identity of the faith community both forms and reflects its members may be helpful in moving forward in our ecumenical efforts. This calls for a ground-up approach as opposed to a top-down approach. By "ground-up" it is meant that the starting point for theological reflection on ecumenism begins not with doctrine but with praxis, particularly as it relates to the common believer in the pew. The ecclesiological model "Body of Christ" provides a helpful vocabulary in this exploration for a number of reasons, none the least that it is scripturally-based, presumes diversity and employs concrete imagery relating to everyday life. Further, "Body of Christ" language is used by numerous Christian denominations in their statements of self-identity, regardless of where they lie on the doctrinal or political spectrum. In this article, potential benefits and challenges of this ground-up perspective will be considered, and a way forward will be proposed to promote ecumenical unity across denomination borders.
\end{abstract}

Keywords: ecumenism; ecumenical; ecclesiology; ekklesia; body of Christ; Christianity; denomination; unity-in-diversity; bilateral dialogue; ressourcement; aggiornamento

\section{Introduction}

Recent decades have witnessed extraordinary ecumenical achievements such as the "Formula of Agreement" providing for the sharing of ordained ministers between several mainline Christian churches (Office of the General Assembly, Presbyterian Church (USA) 2000). ${ }^{1}$ This gives the Christian Church a great deal of hope in the promise of full unity. Yet this level of communion, even among mainline Christian traditions, is the exception rather than the norm, and there remains an enormous amount of work ahead before Christians can declare we live up to the scriptural decree that we are one in Christ Jesus (Gal 3:28). In the face of rapid globalization as well as religious, cultural, and political polarization, it is essential to ask ourselves whether the conventional modus operandi of ecumenical dialogue is sufficient, or even the most effective, manner of proceeding towards full Christian unity.

I propose that focusing on the internal development of the local faith community's denominational identity will enrich ecumenical dialogue. This requires a shift to an ecclesiological approach to ecumenism. An ecclesiological approach reveals the necessity of attending to how the faith community concretely operates and changes in response to ecumenical practices as well as to other forces affecting its sense of identity and well-being. The intention of this focus is to assist the local ekklesia in recognizing and sharing its particular gifts in building up the body of Christ from its "ground," where Christians "live

1 The formal title is, "A Formula of Agreement: The Orderly Exchange of Ordained Ministers of Word and Sacrament." 
and move and have our being (Acts 17:28)." Ecumenical communion can happen most authentically through the internal transformation of the ekklesia.

\section{The Lateral Approach to Ecumenism}

If one takes a long view back, it is safe to say much has been accomplished during the last century in ecumenical relations due to bilateral and multilateral dialogues. "Bilateral" and "multilateral" dialogue commonly refers to talks or agreements between two or more equal bodies conducted by way of appointed representatives; in terms of ecumenical dialogue this is most often official and high-ranking leaders who carry significant authority within a denomination's governing body (Faber 2018). ${ }^{2}$ The result of this type of engagement is joint statements or actions regarding doctrine or practice. Examples are the Lutheran-Catholic "Joint Declaration on the Doctrine of Justification" (Lutheran World Federation and the Catholic Church 1999) ${ }^{3}$ which considers a major doctrinal issue and the above-mentioned more recent "A Formula of Agreement: The Orderly Exchange of Ordained Ministers of Word and Sacrament" between the Evangelical Lutheran Church in America, the Presbyterian Church (USA), the Reformed Church in America and the United Church of Christ which affects a major practice of the Christian Church (Office of the General Assembly, Presbyterian Church (USA) 2000).

There is no argument that such agreements constitute a profound movement of Christian unity. Theological analysis of the Church's doctrines and praxis must be ongoing as the world, and the language we use to communicate in it, shifts and develops. With this theological engagement we have resolved and will continue to resolve fundamental misunderstandings related to sacrament and salvation at the philosophical level.

Despite such an impressive breadth of accomplishment, bilateral and multilateral dialogues have limitations. Eva-Marie Faber lists the lack of coherence and reception as two major limitations, both of which have to do with the distance between what happens during the dialogues, and the "reality within the churches" (Faber 2018, p. 7). Although she does not consider this issue in depth, Faber's analysis indicates the fundamental problem of the disconnect between those who are representing the denominations and what actually goes on within the denominations as well as how ordinary believers understand their faith. Faber points to the difficulty of pluralism, not only between the dialogue partners, but within each of the participating denominations' churches, which must be adequately reflected if the denominations are to be authentically represented, particularly if the partners are representing a tradition with many branches (ibid., pp. 7-8). ${ }^{4}$ This seems at least an impractical, if not nearly impossible, task to be undertaken by a small delegate of officials. Further-and this relates specifically to the issue of reception-unless the shifts in relationship that happen at the bilateral or multilateral level are replicated in the local churches, the conversion and unity that happens as result of dialogue remain a "spiritual ecumenism" only for the officials directly involved (ibid., p. 8). ${ }^{5}$ I would go further in this critique and say that indeed it remains only a "theoretical ecumenism." Faber notes that the kind of attention given early on in ecumenical dialogues has "largely disappeared from the consciousness of the ecclesiastical public" (ibid., p. 9).

I would add to Faber's discussion about the problem of reception that the number of internal issues Christian denominations face today further hinder if not threaten to stall ecumenical progress.

2 Eva Maria Faber presents a good survey of Christian bilateral dialogue in her chapter, Bilateral Dialogues, published in the Oxford Handbook of Ecumenical Studies. Faber is Professor of Dogmatic and Fundamental Theology at the Theologische Hochschule Chur, Switzerland.

3 The Joint Declaration was created in 1999 between the Catholic Church's Pontifical Council for Promoting Christian Unity (PCPCU) and the Lutheran World Federation, and later adopted by other ecumenical bodies, most recently the World Communion of Reformed Churches (2017).

4 Faber's uses the broad diversity of understandings of ministry among Protestant churches as one example.

5 Faber coins a term used at the Second Vatican Council, although she employs this in a somewhat more critical manner, I believe, than it was intended by the Council. 
Many denominations struggle with membership numbers, particularly in the U.S. and Europe (Hackett and McClendon 2017; Lipka 2015). ${ }^{6}$ Changing demographics within denominations regarding ethnicity, age, and mobility challenge long held-cultural presuppositions about the distinctiveness of each denomination (Pew Research Center 2015). In some denominations, the decline in ordination has led to radical shifts in church leadership at the local level. ${ }^{7}$ Further, populist political movements around the world intensify divisiveness not only between but within denominations in terms of members who are "liberals" and "conservatives." Even though we would like to continue claiming that religion cannot be reduced to simplistic political positions, recent research provides compelling evidence that politics heavily influence religious affiliation and relationships (Lipka 2016; Marzouki et al. 2016).

All these factors have a domino effect on the sense of denominational identity, particularly as it relates to the churches and their members at the local level. The impact on ecumenical engagement is profound. Without an abiding and authentic sense of denominational identity, true dialogue, and true unity, cannot progress. Ecumenism is not merely the sum of the commonality of the denominations, nor compromise on doctrine and practice for the sake of agreement, nor the convergence of all the denominations into one dominant or umbrella denomination. The goal of ecumenical unity is greater conformation and representation of the body of Christ in the world. The expression of Christ in the world is what is at stake, a topic that will be considered in more depth presently.

Clearly, bilateral and multilateral engagement is essential. However, even if efforts are intensified, it is obvious that a conventional "lateral" approach will not address the problems inherent within denominations that seriously hinder progress between denominations. If ecumenical success is measured by joint statements and shared practices promulgated by the top-level of the denominations to trickle down to the masses of believers, the Church has little hope of true, lasting and deep ecumenical conversion. I suggest that, while lateral dialogues continue with all available resources and commitment, an additional form of ecumenical work be developed that focuses on the ekklesia, the assembly gathered together in faith, in service and in worship. This approach, linking ecumenism and ekkesia, might be called a "ground-up" approach.

\section{From the Ground versus From the Top}

As Faber notes, the effectiveness of bilateral dialogue on the local ekklesia has been, in many instances, problematic. This is not to say that ecumenical unity does not happen at the local level; certainly it does, and in some communities, profoundly. Rather, there are few official mechanisms to track, implement and assess to what extent and in what manner ecumenical agreements are received at the local level, let alone how this ecumenical development affects the church's self-understanding. Of course, in matters concerning practice such as in the "Formula of Agreement: The Orderly Exchange of Ordained Ministers" there are carefully laid out procedures for implementation. However, there is no provision for assessment at the local level, and nothing to suggest that there be education of the laity regarding the document. More importantly, there is no mechanism with regard to the participation of the laity.

By its very nature, reception in matters of religious faith must entail active participation, not passive acceptance, by all the members of the Church. The lateral approach ultimately presumes the denominations' local churches will eventually get used to, and accept, the changes made by officials.

6 Further research shows that even among those who identify as Christian, a growing number are non-practicing. See the Pew Research Center Report, "Being Christian in Western Europe" (Pew Research Center 2018).

7 The shortage of Roman Catholic priests in the U.S. and Europe is well known, and this trend seems to be occurring in a number of mainline Protestant churches as well as the Episcopal church. See, for example, Leslie Scanlon's in-depth article, in the 26 September, 2017 Presbyterian Outlook, Will there be enough ministers to serve the Presbyterian Church? Available online: https://pres-outlook.org/2017/09/pastoral-pipeline-will-enough-ministers-serve-presbyterian-church/ (Scanlon 2017) and Cameron Nations article, the future of the Episcopal Church's clergy in the 11 August, 2017 Covenant. Available online: https:/ /livingchurch.org/covenant/2017/08/11/the-future-of-the-episcopal-churchs-clergy/ (accessed 30 September 2018) (Nations 2017). 
But experience has shown us that often dissenting members leave the denomination, or the branch of the denomination, that has imposed a change upon them. The ordination of women, and of persons who are LGBT + , are obvious examples of this exodus. On the one hand, the remaining community members are then left to enjoy the new-found ecumenical unity with other like-minded denominations. On the other hand, without the participation of those dissenting members, the community slowly becomes more homogeneous. Far from strengthening self-understanding and a sense of identity and mission, the community is weakened by becoming a silo of uniformity. More consequently, the departure of dissenting members erodes the very unity it strives to create, for the goal of ecumenism is radical inclusivity, and now some members are not only marginalized, but perhaps even spiritually injured. This is not to say such ecumenical agreements should not be made; indeed, they must be made, and accord on issues like the justification of faith, the sharing of ministers and the expansion of who can minister is authentic and essential progress. But ecumenism is not about weeding out people whose faith has not yet reached that level of understanding. It is about transformation of the baptized; it is the baptized who make up the Church. They cannot be excluded simply because they do not agree with changes over which they had no participative role.

There is, I believe, another way. Ecumenism should be done from the ground, focusing on the members of the community and their experience and understanding rather than with denominational doctrines and its leadership. Not only does this create an essential link between ecumenical dialogue and the ekklesia that may be lacking from the more conventional lateral approach-which might be labeled "from the top down" - it opens a space necessary for true reception that lateral dialogue typically does not, that is, the transformation of the members of the community.

An approach "from the ground" explores the ecclesial reality that is non-linear, concrete and organic in nature. In other words, the focus shifts from the two dimensions of "up" and "down," involving church leaders making decisions on behalf of church members, to the sacred space of "ground," where all the members together "move and live and have their being." This metaphor is helpful in understanding the complexity of the ekklesia, because "ground" connotes a richness of multiple dimensions not present in either a lateral field or in the vertical field of "up" and "down." "Ground" is a concrete image that in our first impression brings to mind dirt, clay, mud, and earth. This leads secondly to the images of things that spring up from the ground, life- -trees, grass, wheat, rice and other grains, and flowers of all colors, shapes and sizes. This provokes a third reflection on what lies beneath: the roots, bulbs and nutrients, worms and bugs, and other creepy-crawlies all working together to make that life above thriving and abundant. The term "ground" engages all our senses: the sight of splendid colors, the smell of living and dying things, the taste of the basic staples of food, the touch of the roughness of soil, the mysterious sound of silence where creation itself is continually being born, living, growing, dying and reincarnating. The ground sustains a complex community - a nexus of communities-and is the place of profound ongoing transformation. The ground is a splendid metaphor for the ekkleia.

Indeed the term "ground" is a master metaphor drawn from the history of Christianity, particularly from the mystical tradition, to describe the relationship between God and humanity, which makes it also particularly applicable to ecumenism, whose objective is to create the type of communal life, of communion between denominations, that allows the Christian Church to operate in its imaging of God as a living expression of Christ in the world. The ancient description of the Church as the "body of Christ" communicates the very idea that, through the Christian community's activity, Christ is alive in the world bringing it into greater communion with God, who as the source, sustainer and end of all things, is the very Ground of Being. Like the metaphor of "ground," the body of Christ is an organic notion that expresses a profound unity-in-diversity. Before delving more explicitly

8 Meister Eckhart is most well-known for his use of "ground" as master metaphor. Bernard McGinn (McGinn 2001) explores his concept in chapter 3 of The Mystical Thought of Meister Eckhart: The Man from Whom God Hid Nothing (New York: Crossroad, 2001). 
into the ecclesiological implications of this approach, however, we need to spend a bit more time exploring the metaphorical dimensions of "ground."

The directionality of "up" plays an important role in the metaphor "from the ground up." The ground beneath our feet gives us solid footing, a sense of assurance and safety, a place to be. Meanwhile, the life under our foot breaks through the ground and springs up from its secret womb to become visible, ready to be known and to enter into direct relationship with other living creatures. In other words, life does not stay within the ground but issues forth. Ecumenically speaking, this community activity's breaking through and moving outside of itself is imperative to the life cycle of dialogue both within the faith community and between faith communities. This suggests that many of the challenges and problems denominations are facing "within" must be considered part of ecumenical dialogue, particularly as it relates to their being dealt with as a condition of sustained ecumenical engagement.

Understood in the context of "ground," directional terms such as "up" and "down" lose their imperialism. The so-called "top-down" approach occurs when important things are resolved by official representatives, some of whom are considered "God's appointees" - for example, the ordained clergy, although this is not the case in all denominations. At any rate, those who represent the denominations in dialogue typically hold positions of greater power within their church bodies. These decisions are then disseminated to those who do not hold positions of authority-the laity or faithful masses. This is imperialistic in the sense that some persons within a community are presumed to be more qualified to speak on behalf of the community because of their power, authority, and official position. The official's voice is equated with the community's voice. Agreements made by these persons are then imposed on the community with the presumption that this is what is best for the whole.

A top-down approach must be considered a valid mode of operation by virtue of initial and ongoing efficiency-this is one important role of leadership after all. Moreover, the principle of reception is not necessarily excluded. If official leaders make a decision that is rejected by the members it is doomed ultimately to fail. Further, many denominations take great care in appointing officials who represent the concerns and character of their communities; indeed, some denominations ensure lay persons are involved at every level of their governing structure. This is one way to create a greater connection between decision and reception. However, even at its best, the top-down approach should not be the only or even the primary mode of operation in ecumenical dialogue. Efficiency aside, the top-down model perpetuates a system of power that is contrary to the principles of the beatitudes upon which Christianity is founded, a system where the structures of power are completely overturned. Additionally, and perhaps just as importantly, when used as the primary method of change, the top-down model undercuts the process of deep transformation necessary for the body of Christ to develop within and between communities.

It should go without saying, but perhaps should be reiterated anyway, that any ecclesial change, ecumenical or otherwise, must be theologically well-grounded. In other words, theology matters; and while no theological perspective is perfect or even sufficient to capture the reality of God, nor our communal life in God, not all are equally valid in terms of Christian orthodoxy or equally helpful in articulating a specific dimension of the faith. Since the second half of the twentieth century, the expression "theology from below" has been commonly used to contrast with a more so-called "classical" perspective, deemed theology "from above." Theology "from below" was coined by theologians such as Bonhoeffer, Moltmann and Pannenberg and is widely adopted by liberation, contextual and other contemporary theologians. ${ }^{9}$ Theology from below considers the experience of God as it is found in the unfolding history of salvation, and in the ordinary experience of believers,

9 See, for example, Sabine Plonz's excellent 2004 Bonhoeffer Lecture on Public Ethics, “The view from below: some approaches from a German perspective," which gives an in-depth analysis of the rise of this theology in Germany and its relationship to liberation theology. Dr. Plonz is the Professor of Theological Ethics at Universität Münster. The unpublished text is available online: http:/ / www.sabine-plonz.de/fileadmin/media/downloads/vortraege/Bonhoeffer-Lecture.pdf (Plonz 2004). 
particular those who lack official political or religious power. This is distinguished from the so-called classical approach which tends to be ahistorical, philosophical and authoritarian.

At first glance, it would seem that ecumenism from the ground-up is an expression of theology from below. However, upon digging deeper (pun intended) we find that there might be a third alternative that fits our needs better. Due to its useful and common contrast with a "theology from above," "theology from below" tends towards a two-dimensional perspective and presents an opposition of perspectives. In other words, the contrast between theology from above and from below presumes one is good and one is bad, that one perspective should be abandoned in favor of the other. In ecumenical efforts we should not denigrate or undercut what happens at the top levels. In fact, we need to support dialogue between official leaders, reflect deeply on the philosophical presuppositions, and encourage more communication between levels of authority. I would say, rather, that ecumenism "from the ground-up" is an expression of theology "from within."10

Like theology from below, theology from within begins with the experience of the ordinary believer. It is not a rejection of either classical theology or a theology from below. What the metaphor of "within" adds to this is reflection and analysis is a space for the process of transformation and the forces that shape it, particularly as it relates to issues of identity and potentiality. The connection of the terms "within" and "ground" is a natural one-because it is deep within the ground that the arduous labor of life happens, that something becomes what it is, moving from seed to fruit. Applied ecclesiologically, theology from within attends to some of the intra-denominational issues that hinder ecumenical growth and accentuates potential resources that might be overlooked from a "top" view, much like a gardener tends to the seeds, soil and environment of her field. When applied to the ekklesia, concentration is placed on the dynamic relations between the members and their particular gifts, the faith community and the forces that affect it, including their relationships with other faith communities.

\section{The Body of Christ}

A focus on the ekklesia, the life of the gathered faith community particularly in its denominational identity with all its challenges and its gifts, opens another path to Christian unity. As reflection on the complex structure and inner workings of the church as well as how the Church encounters and engages the world, ecclesiology at its best is done as theology from within, emphasizing the transformative process and potential of the faith community and its members. A ground-up approach will embrace and develop upon ecclesiology as praxis, staying close to what is going on in the mind, heart, body, and actions of the laity, particularly as it relates to the process of reception and engagement with other denominations.

The ecclesiology of the Church as the body of Christ holds much promise for such ecumenical development. The use of the body of Christ imagery not only has deep Scriptural roots, it is widely used to describe the ecumenical unity that already exists in the Church and provides a mandate for ecumenical dialogue to progress. Further, it is used intra-denominationally to describe the local church community. Theologically it draws upon concrete and organic language rather than philosophical language to talk about the faith community's life with each other and in God. The ecclesiology of the body of Christ, therefore, is a good place to develop a ground-up approach to ecumenism.

St. Paul's Chapter 12 of his first letter to the Corinthians is among the most well-known passages in the Christian Scriptures. Beginning with an exhortation on the many gifts the Christian community has to share, he goes on to compare the community members to parts of a body and concludes, "Now you are the body of Christ, and each of you are a part of it" (1 Cor 12:27). The familiarity of this chapter should not dull its shocking implications, particularly as it might have been received in

10 Hans Urs von Balthaser coined the phrase "Christology from within." My use of "theology from within" assumes his use but broadens it to include theological anthropology, pneumatology and ecclesiology; in this article I am using it solely in an ecclesiological sense. For more on von Balthaser's Christology, see Mark McIntosh's Christology from Within: Spirituality and the Incarnation in Hans Urs von Balthasar, Notre Dame: Notre Dame Press, 1996 (McIntosh 1996). 
its original community members, who were struggling with many cultural and religious issues that divided them, including socio-economic disparity and rejection of the religious concept of resurrection of the dead. As Douglas Campbell remarks, the community "was a mess" (Campbell 2017).

Indeed, it is evident that Paul meant his analogy of the body to be a shock to the community. Maria Pascuzzi explains that while the analogy of community as a body was common in antiquity,

usually the analogy was used to conserve the status quo, especially as a means to keep the lower classes in their place and dissuade them from dissent or rebellion that could upset the balance of power. Paul uses the analogy not to subordinate but to stress the diversity, interdependence, and importance of all the members of the community. (Pascuzzi 2005, p. 73)

Two important points can be drawn from these scholars' observations. First, Paul intended his analogy to refocus the way in which the community thought about its identity as well as how they relate to each other. Second, many of the problems that the community struggled with are familiar to the Christian Church today, both at the intra-denominational level as well as at the ecumenical level.

In the public domain, denominations often include identity statements referring specifically to themselves as the body of Christ. For example, the United Church of Christ states: "By our very name, United Church of Christ, we declare ourselves to be part of the body of Christ-the Christian Church."11 Similarly, the United Methodists lay claim to the Church as the body of Christ, "an extension of Christ's life and ministry in the world today."12 The American Baptists sees itself as "Serving as the Hands and Feet of Christ."13 The affiliation of the Church as the Body of Christ is even more apparent when denominations refer to themselves in relation to other Christian denominations, both in the context of explicit ecumenical relations and in general terms. Indeed, denominations such as the United Methodists and the United Church of Christ are careful not to equate themselves with the body such that other denominations are excluded, and implicitly or even explicitly at times recognize that new members bring with them gifts from other Christian traditions.

Since this ecclesiological image already plays a significant role denominationally and ecumenically, it seems sensible to develop it practically. For this purpose, I shall speak of the ecclesiology of the body of Christ in terms of its function as a model. A "model" is something that goes beyond a metaphor or image while retaining their important function of providing access into the depths of reality that plain or "literal" language cannot do. As Avery Dulles famously observes, "when an image is employed reflectively and critically to deepen one's theoretical understanding of a reality it becomes what is today called a model" (Dulles 2002, p. 15). He includes both an explanatory and an exploratory function regarding ecclesiological models, important because the exploratory opens the faith community to the possibility of new theological insights (ibid., p. 17). While conceding to the fact that any one model is certainly inadequate to capture the mystery of the Church, the vocabulary of the body of Christ is particularly helpful precisely because it is already so deeply rooted in the Christian imagination both scripturally and historically, and appeals to denominations across the Christian spectrum.

Dulles treats the ecclesiology of the body of Christ under the umbrella model of "Mystical Communion," following the work of Congar, Hamer, and Mühlen (ibid., pp. 39-54). ${ }^{14}$ Certainly the association of communion is especially relevant to the application of ecumenism. However, I would like to focus more specifically on some characteristics of the body of Christ that are not considered in Dulles' seminal work, particularly the gifts of the Holy Spirit dispersed amongst the members, and the implications for unity-in-diversity within and between denominations.

11 See http://www.ucc.org/about-us_what-is-the-united-church-of.

12 See http://www.umc.org/what-we-believe/our-christian-roots-the-church.

13 See http://www.abc-usa.org/.

14 Dulles draws specifically from Congar's Lay People in the Church (Westminster, Md.: Newman, 1965) (Congar 1965, pp. 28-58 and Hamer's, The Church is a Communion (New York: Sheed \& Ward, 1964) (Hamer 1964). 
Paul lists a number of gifts distributed among the community members, stressing that all are necessary, whether they are normally considered more or less honorable, and he compares them to the parts of a body, again making the rather shocking claim that the less presentable are not only indispensable, but given the greater honor by God. He apparently meant his list of gifts to be representative rather than exhaustive (Pascuzzi 2005, p. 74). This can easily be translated into any Christian community today, looking to the many roles distributed in a local church and I would further apply this to the gift of denominational identity. It is all good for each denomination to recognize and assert that it is part of the body of Christ along with all the other denominations. However, what specific and unique gift does being United Methodist, Roman Catholic, Presbyterian, Southern Baptist, or Quaker lend to the body of Christ? And further, if this conversation of denominational identity and giftedness takes place at the top level but there is little self-understanding or participation from the members of a denomination at the local level, then ecumenically speaking, the exchange of denominational gifts is incomplete, and true unity-in-diversity does not actually exist.

Let us then shift this question to the local level. While it may seem obvious that the pastor of a community has a major role in transmitting the denominational identity to the congregation, how does the liturgical coordinator, the music minister, adult catechist, youth minister do so? How does a teenager or an elder communicate what it means to be a member of their denomination? Denominational identity is more than a statement on a church bulletin or website generically applied to the community as a whole. Identity is something that permeates one's being; it is something that comes from within and moves outward; it is expressed differently according to its diverse expressions in the life of the community. The gift of denominational identity springs forth from the faith community's very ground. It is this gift that should be nourished and cultivated to be shared with others. With this sharing, ecumenism can be seen as a beautiful garden of denominations.

\section{Conclusions: A Way Forward}

In this paper I have endorsed an approach to ecumenism that will not replace but rather support and increase the effectiveness of conventional bilateral dialogue. A "ground-up" approach works, practically and theologically, from "within" in a manner that more deeply connects leaders as representatives to their local ekklesia, which is always in the process of forming itself in authenticity and in dialogue with other faith communities, because it begins with the experiences of the community and not with the official conversation. The consequence of this type of multi-dimensional work is the ongoing transformation of the Church into the body of Christ through discernment and sharing of the gifts of the Spirit.

This work is, of course, already going on both officially and unofficially in many denominations; however, it would be more effective if done explicitly and consciously and on a wider scale. Denominations concerned with membership decline are striving to retain current members and recruit new ones, particularly youth, by highlighting features attractive to contemporary culture, such as inclusiveness, diversity and social media. The positive effect is that it forces churches out of their denominational silos, and in fact this brings denominations closer together in certain respects than it may otherwise. Consider, for example, the issue of homosexuality that has, in recent history and today, been so divisive within society and religion alike. Denominations that reject homosexuality on the grounds of a literalistic interpretation of the Bible have to contend with young adults who are unwilling to exclude friends, or parents who are unwilling to exclude their children, for this reason. The result is change in the language denominations use to talk about this issue if not actual changes in policy or doctrine (Murphy 2015). This brings branches within denominations formerly split along these lines into closer alignment and creates areas of agreement between denominations with differing doctrines and practices.

On the other hand, the appeal to recruit new members through a sense of broad inclusivity in some cases has the effect of eroding denominational identity to the extent that members understand the church they are attending to be "non-denominational" - even if it is not. Hence, commitment to a 
particular church rests on what a person is getting from it rather than participation in the building up and manifestation of the body of Christ within that community or at the denominational level. When a church body goes through a period of difficulty, it is easier for members to leave and find another local community that meets their needs, without much regard to its underlying theological allegiance. This lack of denominational commitment or "church shopping" decomposes the body of Christ and ultimately erodes ecumenical dialogue because a growing number of members are theologically uneducated, unaware of, confused about or uninterested in the very doctrines and practices that bring the leaders of denominations to the dialogue table. At the level of the local community, some churches become more like homogenous social clubs than vital organs of a complex living body. If the body of Christ is to function as a body, there must be true unity-in-diversity regarding doctrine and practice as well as self-understanding among the various member denominations.

Ecumenical unity is enhanced through the sharing of denominations' unique identities, considered gifts of the Holy Spirit. It is therefore important that each denomination engage in serious and sustained development from within their congregations, particularly in the local faith community. This involves, at the most basic level, ongoing catechesis about the denomination's history, doctrines and distinctiveness, which should be readily available to church members as well as to visitors. Historical education must include honest reflection of divisions, controversies, and violence without vilifying those with whom the divisions occurred. Similarly, the denomination's history of ecumenical engagement, both successes and failures, is also essential, along with reflection on how this engagement has shaped the denomination as it currently exists. Ongoing catechesis should be done from childhood through adulthood. Further, a denomination's identity should be made apparent to those who are visiting or considering membership. This should go beyond the extremely general statements drawn from the Creed many churches include on their websites under "what we believe."

Of course, most denominations have programs of education and include information about their churches on their websites. However, in too many cases information is being disseminated in a less than effective manner. Christians should have a sense of shared identity and ownership in their denominations. But this is yet not enough, for the body of Christ is a sharing of gifts and building up of the body for the sake of representing Christ in the world. Being knowledgeable and proud about one's denominational identity is one thing; being able to develop and grow with that identity, and in relationship to others, is something else. If the body is to be living, it must also be in the process of continual transformation. As members understand themselves as gift in terms of their denominational identity, they must also be encouraged to share their personal gifts within the community to transform it into its best form as a part of the body of Christ.

I suggest that the twin movements developed by the Second Vatican Council, ressourcement and aggiornamento, applied at the denominational level may be helpful in developing a ground-up approach. Ressourcement, a return and retrieval of the history, sources and symbols of faith, and aggiornamento, bringing up to date, with attention to the "signs of the times" provided the dynamism that brought the Roman Catholic Church into the twentieth century. These movements work together; what is retrieved is creatively adapted to respond to contemporary issues.

Indeed, these movements might be applied to the local and denominational ekklesia causing the kind of deep transformation that breaks through ecumenically like richly nourished ground breaks through with all manner of life. For example: cultivating a genuine understanding of one's denominational history and sources through ongoing catechesis will include multiple contexts that helps members of a community discern its distinctive character in ways that do not keep it stuck in the past with the same issues that caused the body of Christ to splinter in the first place. It is important, for example, to recognize the sinful conditions that were confronted at times of schism, be it abuse of authority or theological distortion, without holding prejudice over the branches or denominations that were involved. Equally important is to separate political, cultural and theological motivations at play during a particular historical period. Finally, the prophetic quality of a denomination's founders should be preserved and celebrated without pitting him or her with the founders of other denominations, 
even if there is significant theological disparity between them. This should also lead, ecumenically, to a renewal in the practice of forgiveness and reconciliation, which may be celebrated in shared worship between local denominations. To sum it up, members of a denomination should have more than a summary or general understanding of their own history if they are going to be committed to their faith community in a way that develops their gifts and allows them to share it ecumenically, and they should be given the space and encouragement to put this into shared practice.

In terms of aggiornamento, let us return to local community as the ground of experience and primary source for discerning the "signs of the times" and determining the theological and practical priorities for ecumenical dialogue. Denominational catechesis is but a first step in building up the local community and improving relations between faith communities. It is also important that churches develop their sense of spiritual relevance in the modern world. Many denominations are pressured to find ways to attract and retain members as a matter of survival; however, contemporary marketing strategies will not stop the decline in mainline churches in North America and Europe. While it is natural to be concerned with how many members a denomination boasts to show how important and relevant a church is, perhaps the focus should be on the quality and health of the body of the church. The focus of ecumenism is, after all, not on how big Christianity is, but on how well it manifests the body of Christ in the world. Secular sports clubs, coffee shops, and self-help groups already provide many of the services people need, and unfortunately these seem to have replaced belonging to a church for many persons. But these secular communities cannot create the body of Christ and do not provide what is needed in the world, spiritual transformation. Spiritual growth is not just finding a place to feel comfortable in your own skin-although church communities certainly should affirm the personal and human dignity of its members and be warm, inviting, inclusive, and safe spaces for all. Having provided that space it should go on to challenge members to participate fully in the life of the church, and grow beyond themselves in understanding who they are as a member of that faith community, so that they can confidently and genuinely share their gift with their sisters and brothers in other Christian churches and with the world.

Conflicts of Interest: The author declares no conflict of interest.

\section{References}

Campbell, Douglas. 2017. Paul wrote 1 Corinthians to a community in the middle of a culture war. Christian Century. December 22. Available online: https://www.christiancentury.org/article/critical-essay/paulwrote-1-corinthians-community-middle-culture-war (accessed on 8 October 2018).

Congar, Yves. 1965. Lay People in the Church. Westminster: Newman, pp. 28-58.

Dulles, Avery. 2002. Models of the Church. New York: Doubleday. First published 1974.

Faber, Eva-Maria. 2018. Bilateral Dialogues. In Oxford Handbook of Ecumenical Studies. Edited by Geoffrey Wainwright and Paul McPartian. Oxford: Oxford University Press, pp. 1-14. Available online: www.oxfordhandbooks.com (accessed on 1 October 2018).

Hackett, Conrad, and David McClendon. 2017. Christians Remain World's Largest Religious Group, but They Are Declining in Europe. Pew Research Center Report. Available online: http:/ / www.pewresearch.org/facttank/2017/04/05/christians-remain-worlds-largest-religious-group-but-they-are-declining-in-europe/ (accessed on 1 October 2018).

Hamer, Jean Jérôme. 1964. The Church Is a Communion. New York: Sheed \& Ward.

Lipka, Michael. 2015. Mainline Protestants Make up Shrinking Number of U.S. Adults. Pew Research Center Report. Available online: http:/ / www.pewresearch.org/fact-tank/2015/05/18/mainline-protestants-makeup-shrinking-number-of-u-s-adults / (accessed on 1 October 2018).

Lipka, Michael. 2016. U.S. Religious Groups and Their Political Leanings. Pew Research Center Report. Available online: http:/ / www.pewresearch.org/fact-tank/2016/02/23/u-s-religious-groups-and-theirpolitical-leanings / (accessed on 1 October 2018). 
Lutheran World Federation and the Catholic Church. 1999. Joint Declaration on the Doctrine of Justification. Available online: https:/ / www.lutheranworld.org/sites/default/files/Joint\%20Declaration\%20on\%20the\% 20Doctrine\%20of\%20Justification.pdf (accessed on 1 October 2018).

Marzouki, Nadia, Duncan McDonnell, and Oliver Roy. 2016. Saving the People: How Populists Hijack Religion. Oxford: Oxford University Press.

McGinn, Bernard. 2001. Eckhart and the Mysticism of the Ground. Ch. 3. In The Mystical Thought of Meister Eckhart: The Man from Whom God Hid Nothing. New York: Crossroad.

McIntosh, Mark. 1996. Christology from Within: Spirituality and the Incarnation in Hans Urs von Balthasar. Notre Dame: Notre Dame Press.

Murphy, Cayrle. 2015. Most U.S. Christian Groups Grow More Accepting of Homosexuality. Pew Research Center Report. Available online: http:/ /www.pewresearch.org/fact-tank/2015/12/18/most-u-s-christian-groupsgrow-more-accepting-of-homosexuality/ (accessed on 1 October 2018).

Nations, Cameron. 2017. The Future of the Episcopal Church's Clergy. Covenant. August 11. Available online: https: / /ivingchurch.org/covenant/2017/08/11/the-future-of-the-episcopal-churchs-clergy/ (accessed on 30 September 2018).

Office of the General Assembly, Presbyterian Church (USA). 2000. A Formula of Agreement: The Orderly Exchange of Ordained Ministers of Word and Sacrament. Available online: http:/ / download.elca.org/ELCA\%20Resource\%20Repository/The_Orderly_Exchange.pdf?_ga=2. 155120632.1312680256.1537549805-1433914763.1535999098 (accessed on 30 September 2018).

Pascuzzi, Maria. 2005. New Collegeville Bible Commentary New Testament. First and Second Corinthians. Collegeville: Liturgical Press, vol. 7.

Pew Research Center. 2015. The Shifting Religious Identity of Demographic Groups. Ch. 4. America's Changing Religious Landscape. Available online: http://www.pewforum.org/2015/05/12/chapter-4-the-shiftingreligious-identity-of-demographic-groups / (accessed on 1 October 2018).

Pew Research Center. 2018. Being Christian in Western Europe. Available online: http:/ /www.pewforum.org/ 2018/05/29/being-christian-in-western-europe/ (accessed on 1 October 2018).

Plonz, Sabine. 2004. The View from Below: Some Approaches from a German Perspective, Bonhoeffer Lecture on Public Ethics, October 11. Available online: http:/ / www.sabine-plonz.de/fileadmin/media/downloads / vortraege/Bonhoeffer-Lecture.pdf (accessed on 30 September 2018).

Scanlon, Leslie. 2017. Will There Be Enough Ministers to Serve the Presbyterian Church? The Presbyterian Outlook, September 26. Available online: https:/ / pres-outlook.org/2017/09/pastoral-pipeline-will-enoughministers-serve-presbyterian-church/ (accessed on 30 September 2018).

(C) 2018 by the author. Licensee MDPI, Basel, Switzerland. This article is an open access article distributed under the terms and conditions of the Creative Commons Attribution (CC BY) license (http://creativecommons.org/licenses/by/4.0/). 